\title{
Review
}

SKiำ

Pharmacology

Physiology
Skin Pharmacol Physiol 2017;30:66-75

DOI: $10.1159 / 000458416$
Received: August 5, 2016

Accepted after revision: January 26, 2017 Published online: March 15, 2017

\section{Stingless Bee Honey, the Natural Wound Healer: A Review}

\author{
Mohd Azri Abd Jalil ${ }^{a}$ b Abdul Razak Kasmuri ${ }^{a} \quad$ Hazrina Hadi ${ }^{a}$ \\ ${ }^{a}$ Faculty of Pharmacy, and ${ }^{b}$ Faculty of Nursing, International Islamic University Malaysia, Kuantan, Malaysia
}

\section{Keywords}

Antioxidant · Anti-inflammation · Moisturizing properties .

Stingless bee honey . Wound healing

\begin{abstract}
Background: The stingless bee is a natural type of bee that exists in almost every continent. The honey produced by this bee has been widely used across time and space. The distinctive feature of this honey is that it is stored naturally in the pot (cerumen), thus contributing to its beneficial properties, especially in the wound healing process. Methods: In this article, several studies on stingless bee honey that pointed out the numerous therapeutic profiles of this honey in terms of its antioxidant, antimicrobial, anti-inflammatory, as well as moisturizing properties are reviewed. All of these therapeutic properties are related to wound healing properties. $\boldsymbol{R e}$ sults: Antioxidant in stingless bee honey could break the chain of free radicals that cause a detrimental effect to the wounded area. Furthermore, the antimicrobial properties of stingless bee honey could overcome the bacterial contamination and thus improve the healing rate. Moreover, the anti-inflammatory attribute in this honey could protect the tissue from highly toxic inflammatory mediators. The moisturizing properties of the honey could improve wound healing
\end{abstract}

by promoting angiogenesis and oxygen circulation. Conclusion: The application of honey to the wound has been widely used since ancient times. As a result, it is essential to understand the pharmacological mechanism of the honey towards the physiology of the wounded skin in order to optimize the healing rate in the future.

(c) 2017 S. Karger AG, Basel

\section{Introduction}

\section{Stingless Bees}

There are approximately 500 species within the stingless bee genus, with the majority of these species being located in Latin America, the mainland of Australia, Africa, and Eastern and Southern Asia [1]. Stingless bees can be classified into 2 genera, namely, the Melipona and the Trigona. The Melipona genus is numerically large, even larger than that of the common honey bee (Apis mellifera Linnaeus) [2]. Stingless bees also play an important role in the ecology, economy, and culture. They act as the main pollinators for many wild and cultivated tropical plants [3]. Their products such as honey, pollen, and cerumen have been used as a source of income for generations. In addition, stingless bees are attached to the cul-

\section{KARGER}

() 2017 S. Karger AG, Basel

E-Mail karger@karger.com

www.karger.com/spp
Hazrina Hadi, BPharm, PhD

Faculty of Pharmacy, International Islamic University Malaysia Bandar Indera Mahkota

Kuantan, Pahang 25200 (Malaysia)

E-Mail hazrina@iium.edu.my 


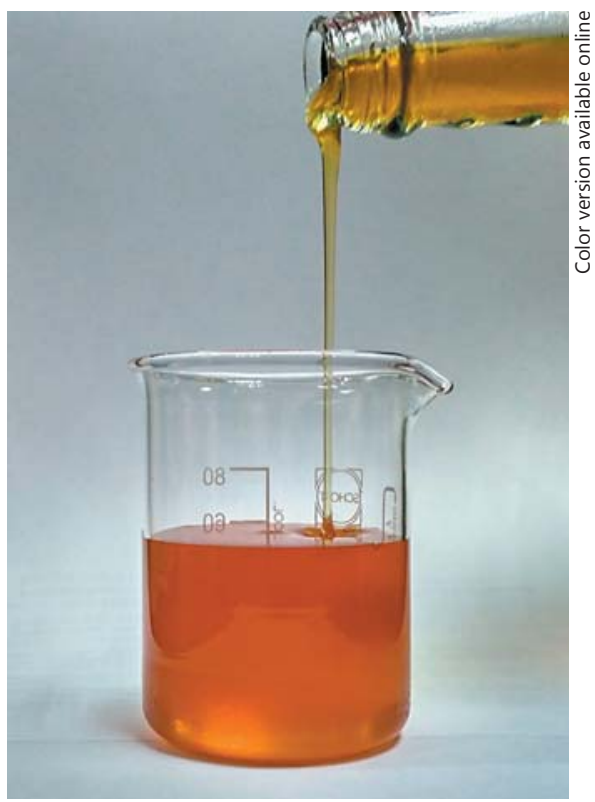

Fig. 1. Stingless bee honey.

ture of indigenous people, especially the Mayan, in rural areas of America [4].

According to a research officer in the Malaysian Agricultural Research and Development Institute (MARDI), the specialty of the stingless bees is the ability to pollinate small-sized flowers due to their diminutive figure which cannot be achieved by the relatively big honey bee. Besides, the stingless bees are not choosey in building a colony hive. As a result, it is easier to build an artificial hive to manipulate the colony and increase the honey production. As the name suggests, the stingless bees do not sting; thus, it is easier to extract the honey, pollen, and propolis frequently. Furthermore, stingless bees are easier to handle compared to honey bees that are often lost, always abandon their hive, and are vulnerable to disease [5]. Likewise, stingless bee honey is unique as it originates from the rich vegetation in native environments. It has a distinctive sweetness mixed with a sour and acidic taste. The appearance of stingless bee honey is displayed in Figure 1 . In contrast to the stingless bee population, the distribution of this honey is lower compared to that of the common honeybee. This is due to the limited knowledge about this honey, which has resulted in it being less popular in terms of its industrial production, shelf life, and quality standard [6]. Therefore, stingless bee honey should be further explored due to its mass production and convenience of management.

Stingless Bee Honey, the Natural Wound Healer
Cerumen and Honey Production in the Pot

Another beneficial product from the stingless bee is "propolis," geopropolis, or cerumen, as it is exclusively known, in order to avoid confusion with A. mellifera propolis. Propolis is a natural resinous and waxy product that is produced by mixing beeswax and resins collected from a variety of plant parts by A. mellifera bees [7]. On the other hand, cerumen is a mixture that is similar to propolis but with the addition of the mandibular secretion of the stingless bee during its construction $[8,9]$. The functions of these products are slightly different, where the cerumen is used as a storage pot for the honey and to mummify trespassers as well as to ensure that the environment in the hive is sterile, while the propolis is used as an internal layer and for sealing the extra space surrounding the hexagon-shaped nest combs. Consequently, due to the storage of honey in the cerumen pots, the quality of the stingless bee honey is influenced by the infiltration of phytochemicals from the cerumen $[10,11]$.

In the cerumen pots, the nectars have to go through 3 different transformation processes before turning into honey. The first transformation is a physical change, where a large part of water evaporates from the nectar. Then, a biological transformation takes place, which is mainly a fermentation process by yeast and bacteria. These microorganisms originate from a suitable microenvironment chosen by the bee and play a symbiotic role with the colony $[12,13]$. Lastly, a chemical transformation occurs when the worker bees secrete the enzymes from their cephalic glands that are able to hydrolyse the nectar's sucrose into fructose and glucose $[12,14]$. Although it is hard to refute that the characteristics of honey vary depending on the bee species, nectar sources, and climate, the noteworthy similarity in stingless bee honey is the water content that is commonly higher than in other types of honey $[15,16]$. As a result, the rich water condition invites the microorganism to inhabit and thrive inside the honey. Most of these microorganisms are probiotics with their beneficial enzyme secretion that works along with the enzymes from the stingless bees to enrich and conserve the quality of the honey $[12,17]$.

\section{Wound Healing}

Wound healing is an outstanding biological process for the restoration of the integrity of the skin after injury. It can be divided into 4 overlapping phases, which are haemostasis, inflammation, proliferation, and remodelling [18]. Figure 2 summarizes the main phases in the wound healing process. Wounds that fail to progress into the normal stage of healing are recognized as delayed 
Fig. 2. Main phases in the wound healing process. ROS, reactive oxygen species; ECM, extracellular matrix; MMP, matrix metalloproteinase.

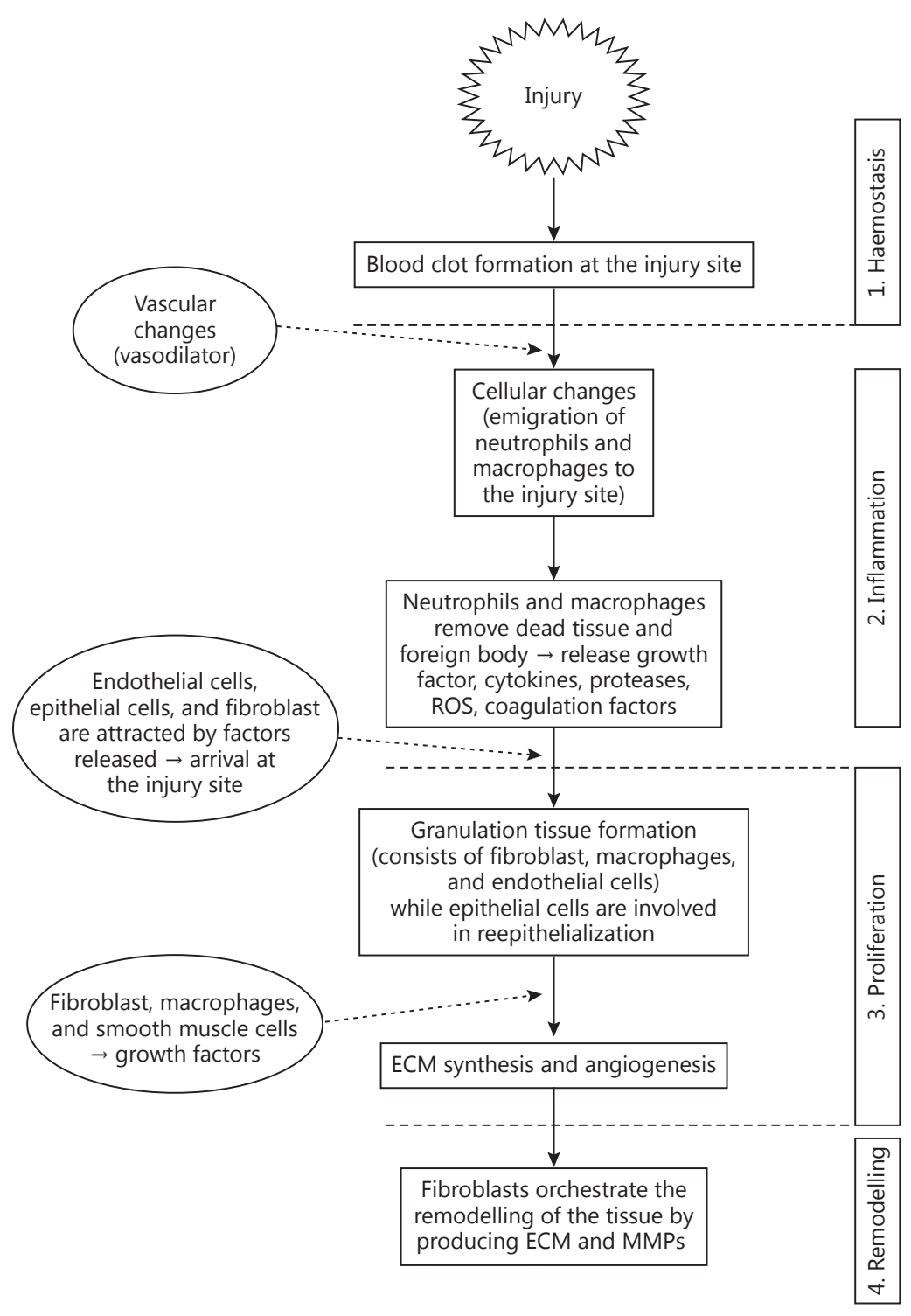

acute wounds and chronic wounds. This impaired healing of a wound occurs due to a postponed, incomplete, or uncoordinated healing process. The factors that significantly cause an abnormal progression in wound healing are oxygenation, infection, age and sex hormones, stress, diabetes, obesity, medications, alcoholism, smoking, and nutrition [19].

\section{Mechanism of Wound Healing by Honey}

As mentioned before, surgeons from the ancient Egyptian era used honey for the treatment of open wounds.
However, although they did not understand the mechanism of cellular biology and microbiological theory, they believed in the use of natural antiseptics and antibiotics like honey to dress wounds in order to prevent infection as well as to increase the rate of healing [20]. Honey is blessed with several wound healing properties that make it an ideal active element in formulations for the dressing of wounds. Firstly, since honey is a natural agent, it is aesthetically pleasing. Furthermore, honey is able to keep a wound in a sanitary condition by means of the wound debridement process, thus creating good deodorization 
Table 1. The components of stingless bee honey that can enhance the wound healing rate
Ref. No.

$\begin{array}{ll}\text { Sugars: mainly glucose and fructose } & 6 \\ \begin{array}{l}\text { Proteins, vitamins, and minerals } \\ \text { Peroxide component: glucose oxidase for the production of }\end{array} & 6 \\ \quad \text { hydrogen peroxide and D-gluconic acid } & 44 \\ \begin{array}{l}\text { Non-peroxide components (flavonoids, polyphenols) } \\ \text { High acidity }\end{array} & 104 \\ \text { High water content } & 15,105\end{array}$

for the wound [21, 22]. In addition to these properties, honey promotes angiogenic activity, which is important in wound healing mechanisms, and also induces the formation of granulation tissue as well as skin reepithelialization [23, 24]. Several studies have indicated other fascinating bioactivities of honey such as antinociceptive $[25,26]$, immunomodulatory $[27,28]$, and nematicidal activities $[29,30]$. The main active mechanisms of honey that are involved in the healing of wounds are its antioxidant, antibacterial, and anti-inflammatory properties. All of these properties will be explained in greater detail later in this paper. Table 1 reveals the components of stingless bee honey that may contribute to the enhancement of wound healing.

\section{Stingless Bee Honey as Antioxidant}

\section{Effects of Reactive Oxygen Species on Wounds}

Antioxidants are agents that save cells from the harmful effects of reactive oxygen species (ROS). Examples of ROS are singlet oxygen, superoxide, peroxyl, and hydroxyl radicals. These ruthless free radicals originate from endogenous stressors, resulting from natural by-products of cellular metabolism, or exogenous stressors such as UV light, pollutants, drugs, smoke, or radiation $[31,32]$. As their name suggests, these reactive molecules provoke the deterioration of membranes, lipids, amino acids, and DNA [33]. The damage to the DNA can lead to the breakdown of collagen, thus disrupting the proliferation stage in the wound healing process.

In the haemostasis stage at the beginning of the wound healing process, vasodilation takes place around the wounded tissue. However, overstimulation of vasodilation caused by inducible nitric oxide synthase (iNOS) may lead to the production of hydrogen peroxide and other ROS $[34,35]$. These free radicals can generate oxidative stress and further worsen the condition of the wounded tissue. The accumulation of ROS will not only harm the wounded site but also spread it across other organs in the body. ROS can activate various humoral and cellular mediators to initiate the inflammation process at the distant organs $[36,37]$.

\section{Role of Antioxidants in Enhancing the Wound Healing Process}

Antioxidants act as a saviour to the structure of cells by neutralizing ROS and thus terminating the damaging chain reaction in the body. Antioxidants can be categorized into 2 types, namely, enzymatic and non-enzymatic antioxidants [38, 39]. Enzymatic antioxidants transform a free radical into a stable molecule that is less harmful to the body. These antioxidants can be further classified into several classes, which are ascorbate peroxidases, catalase, superoxide dismutase, glutathione peroxidase, glutathione reductase, and glutathione S-transferase [40-42]. On the other hand, the non-enzymatic antioxidants block and cut the damaging chain reaction caused by ROS or even inhibit the formation of free radicals. Examples of these antioxidants are ascorbic acid, tocopherol, carotenoids, and phenolic compounds [42].

\section{Antioxidant Properties of Stingless Bee Honey}

The major therapeutic action of honey in improving the wound healing process comes through its antioxidant activity since it can prevent the detrimental effects on the wounded site caused by oxidative stress [43]. It can be postulated that the antioxidant effects of stingless bee honey can also be applied to the treatment of wounds since its antioxidant content is higher or similar to that of other types of honey. Research on the stingless bee (Meliponini tribe) in Australia indicated that the honey produced contains a higher level of flavonoids than the honey produced by $A$. mellifera. The total antioxidant activity in the Tetragonula carbonaria (stingless bee) honey was proven to be higher than that of the European floral honey, while its radical scavenging activity is equal to that of the European floral honey [44]. These findings are supported by 
another research study on the Melipona fasciculate (another stingless bee species), where the content of polyphenol in this stingless bee honey is the highest in comparison with other South American honey bees [45]. In Malaysia, the researchers from MARDI have revealed that the major free phenolic acid in stingless bee honey consists of protocatechuic acid (PCA) and 4-hydroxyphenylacetic acid [46]. PCA is a strong antioxidant that can improve cell proliferation in the wound healing process [47], whereas 4-hydroxyphenylacetic acid is able to scavenge the reactive oxygen and nitrogen species $[48,49]$.

As a matter of fact, another product generated from stingless bees, such as cerumen, also has antioxidant properties [50,51]. In an in vitro study using 5-lipoxygenase (5-LOX) cell-free assays, the polar extract of cerumen has shown the ability to suppress the catabolism of linoleic acid, thus displaying a potent antioxidant effect that can prevent lipid peroxidation and protect the integrity of the cell membranes [11]. In addition, it has been shown that the ethanol extract of cerumen possesses antioxidant properties that reduce the number of ROS and protect human erythrocytes from lipid peroxidation in an antioxidant assay by using a human erythrocyte model [39]. This action is attributed to phenolic compounds, which are important antioxidant components that inhibit haemolysis in erythrocytes [52]. The high antioxidant content in stingless bee honey may provoke interest in the application of this honey in wound healing research.

\section{Antimicrobial Role of Stingless Bee Honey}

\section{The Presence of Microorganisms Could Delay the Healing Process}

Microorganisms exist inside all wounds but the majority of them do not infect the wound, and the wound will heal eventually. This situation happens when the host's immune system and the bioburden of the wound are in a state of equilibrium. Bioburden is a condition where an object is contaminated by a number of bacteria [53]. Nevertheless, if the bioburden overcomes this balance, or there is impairment in the wound healing process, the bacteria will proliferate and occupy the host's tissues [54, 55]. The invasion of foreign bodies into a wound could hinder the healing process and may eventually cause the formation of a granuloma or an abscess. If no action is taken, another problem will arise later, where the leftover collagen produced during the prolonged wound healing process will build up keloid scars $[56,57]$.
As previously mentioned, there are several microorganisms present in the cerumen during honey production. There is some conundrum whether this may impact the healing process when applying honey to the wound. These microorganisms cannot hinder the healing process since most of them have been identified as non-pathogenic which are from the Bacillus genus $[58,59]$ and actinomycete Streptomyces [60]. In contrast, several notorious bacteria like Escherichia coli, Pseudomonas aeruginosa, Staphylococcus aureus, Clostridium, and Coliform species tend to disturb the healing process $[61,62]$. As a consequence, a prolonged and abnormal inflammatory response will occur together with tissue damage and delayed healing. If this situation is prolonged, it may worsen and can lead to systemic illness. Therefore, an intervention should be introduced immediately after the injury as a precautionary measure [53]. A nursing approach to wound healing focuses on preventing pathogenic colonization and eradicating these foreign invaders that are causing the wound healing process to remain at a stagnant phase [63].

\section{Antimicrobial Mechanism of Stingless Bee Honey against Infection}

The main point of antimicrobial or antibacterial applications is to prevent or confront infections, especially during the injury period. Stingless bee honey can be used as an antibacterial ingredient in pharmaceutical formulations since it possesses antimicrobial and antiseptic properties. The antimicrobial activity of stingless bee honey was validated by using the Kirby-Bauer antibiotic test, the agar dilution test, broth microdilution, and time-kill viability assays [10, 64, 65]. This study was supported by researchers from Brazil where they found that stingless bee honey has the ability to inhibit the growth of grampositive and gram-negative bacteria [66]. A unique feature of stingless bee honey is that it is stored in cerumen pots made of wax and propolis. Choudhari et al. [67] found that propolis from India has a compelling antimicrobial property. Similarly, Campos et al. [39] also discovered that propolis samples in Brazil contain broad antimicrobial properties. Therefore, the quality of the honey stored in the propolis-infused cells is influenced by its beneficial content.

The antibacterial effect of honey can be divided into peroxide and non-peroxide components [68]. The peroxide component is based on the activity of hydrogen peroxide. Hydrogen peroxide is regulated by 2 important enzymes in honey, namely, glucose oxidase and catalase. Glucose oxidase induces the production of hydrogen peroxide, while 
catalase will destroy the hydrogen peroxide in order to preserve the nutritional content of the honey $[69,70]$. Hydrogen peroxide will enhance the production of cytokines for the inflammatory response to kill the bacteria $[22,71]$. The non-peroxide components are based on phytochemicals, high sugar content, and the acidity of the honey. The phytochemical components in honey that contribute to the antibacterial effects are flavonoids, phenolic substances, and antibacterial peptides [72]. These components may act by directly inhibiting phagocytosis, thus preventing the superoxide free radicals from damaging the tissues. The last nonperoxide component is the acidity in the honey caused by organic acids. These acids, which make up $0.57 \%$ of the honey itself, will suppress the majority of the microorganisms that grow in a $\mathrm{pH}$ of between 7.2 and 7.4 [73].

In stingless bee honey, the antibacterial effect is influenced by non-peroxide activity. It is uncommon to observe non-peroxide activity in A. mellifera honeys, but Temaru et al. [10] have demonstrated strong non-peroxide activity in a variety of samples of stingless bee honey across the world. An entomological study by Stow et al. [74] has indicated that cuticular antimicrobial compounds that have been secreted from stingless bee honey are responsible for preventing microbial growth. From this finding, Irish et al. [64] have postulated that the non-peroxide activity of stingless bee honey has a connection with the anatomical structure itself of the stingless bee. The non-peroxide activity has a more significant and substantial mechanism in antimicrobial action. Since there is a limitation of its counterpart; the peroxide activity is limited by the presence of catalase in the human body [75]. Therefore, with these coveted antibacterial properties, the application of stingless bee honey on the wounded area may decrease microbial infection and thus rapidly initiate the healing process.

\section{Anti-Inflammatory Role of Stingless Bee Honey}

\section{The Inflammation Effect on Wound Healing}

Initially, inflammation is a beneficial biological response of the blood vessels to any potentially dangerous threat. It is a complex protective effort by the body to remove the harmful agent and to immediately instigate the healing process. Macrophages play an important role in this defence mechanism by increasing the production of proinflammatory cytokines, nitric oxide (NO), and prostaglandin $\mathrm{E} 2\left(\mathrm{PGE}_{2}\right)$. All of these inflammation mediators are highly cytotoxic and are involved in the innate response by killing the target cells $[76,77]$. In spite of their beneficial effects, the overproduction of these mediators

Stingless Bee Honey, the Natural Wound Healer by the activated macrophages may cause tissue damage that can lead to chronic diseases and impaired wound healing [78]. The introduction of an anti-inflammatory agent can control the activated macrophages as well as the production of the inflammatory mediators.

The bad news is that most of the anti-inflammatory pharmaceuticals are not compatible with wound healing. For instance, non-steroidal anti-inflammatory drugs (NSAIDS) are cytotoxic to the tissues, while corticosteroids can inhibit the development of epithelial tissues. In several animal studies, the use of NSAIDS, such as ibuprofen, has a negative impact such as an antiproliferative effect that can cause a numerical decline in fibroblasts, minimized wound contraction, deferred epithelialization, and most importantly, impaired blood vessel formation $[19,79,80]$. As a result, wound care products make little reference to antiinflammatory action, even though inflammation is still the main cause of delays in the healing of chronic wounds [81]. Inflammation results in fibrosis, which can be a source of hypertrophic scars in cutaneous wounds [82].

Anti-Inflammatory Mechanism of Stingless Bee Honey In contrast to most anti-inflammatory drugs, honey, which possesses anti-inflammatory properties, results in less scarring from the healing of wounds caused by burns [83]. The anti-inflammatory effect in stingless bee honey is more prominent in the cerumen. In the in vitro study along with the antioxidant test, Massaro et al. [11] reported that the anti-inflammatory mechanism in the cerumen extract in stingless bee products inhibits the 5-LOX enzyme that is responsible for the synthesis of proinflammatory mediators. Similarly, Franchin et al. [84] found that the ethanolic extract of geopropolis (another name for cerumen) significantly reduces the level of proinflammatory cytokines.

The anti-inflammatory property in honey is contributed by phenolic compounds. Several studies have proven that phenolic compounds can inhibit the overproduction of inflammatory mediators such as NO [78], TNF- $\alpha$ [85], and $\mathrm{PGE}_{2}$ [86]. Besides, phenolic compounds act as free radical scavengers that can protect cells from cytotoxicity induced by proinflammatory mediators $[87,88]$. Therefore, this will reduce the inflammation period in the wound healing stage and thus enhance the rate of healing. Furthermore, honey can also reduce oedema, thus eventually lowering the microvascular hydrostatic pressure on the wound tissue. Oedema constrains the access to oxygen and nutrients that are essential for tissue growth in wound healing [89]. The anti-inflammatory agents have a similar correlation with antioxidants in terms of dealing

Skin Pharmacol Physiol 2017;30:66-75 DOI: $10.1159 / 000458416$ 
with ROS. Stingless bee honey contains both of these elements, which strengthens its ability to counteract all of the detrimental effects in the inflammation process.

\section{Stingless Bee Honey as a Natural Moisturizer for Wound Healing Treatment}

\section{Moisturizer as Wound Healing Enhancement}

In an earlier period, the emphasis of wound care management was on covering the wound to preserve dryness around the wound. This was achieved by removing excess exudates and by protecting the wound against infection [90]. However, since 2003, clinicians and researchers have introduced the concept of "tissue, infection/inflammation, moisture, and edge," which goes by the acronym of TIME [91, 92]. This moisture-friendly approach has become the standard in wound care strategy.

A moist surrounding for the wound can prevent secondary infections and create effective oxygen circulation [93]. Besides that, a moist condition can impede desiccation and necrosis, enhance the formation of blood vessels and connective tissues, as well as rehydrate dried out tissues $[55,90]$. In fact, the application of a moisturizer to the wound can not only relieve the pain but also reduce the possibility of the appearance of scars later on [94]. On the other hand, it is essential to avoid wound dryness because a dry environment can delay the migration of epidermal cells and slow down autolysis and the proteolytic action for tissue regeneration [95].

\section{Moisturizing Effect of Stingless Bee Honey}

Like other types of honey, stingless bee honey also has a high moisture content. A physicochemical analysis by Oddo et al. [44] revealed that the moisture content in stingless bee ( $T$. carbonaria) honey is relatively higher than that in A. mellifera honey. Honey has good moisturizing properties due to the presence of hydroxyl groups. The basic components of honey, which are sugars, proteins, and lactic acid, can act as moisturizers [96]. In addition, the presence of glycerine, propylene glycol, and sorbitol, which are frequently applied as solvents in cosmetics, can enhance the moisturizing properties of the honey $[97,98]$. Several studies have suggested that ingredients such as vitamins $\mathrm{B}, \mathrm{E}$, and $\mathrm{K}$, together with several good minerals like potassium, phosphorus, and calcium that are present almost in all honeys, contribute to the hydrating attributes of honey [99-101].

The high water content in stingless bee honey prevents dehydration to the wound because of the osmotic effect that gradually delivers fluid to the wound tissue $[88,102]$. This will maintain a moist environment around the wound tissue and, as mentioned before, will accelerate the healing, even though a continuous moist condition can develop into a wet condition leading to maceration of the wound [103]. Fortunately, the high osmolarity of the honey can protect the skin from maceration and continuously maintain the moist surrounding [102].

\section{Conclusion}

In conclusion, it is important to take a serious note concerning wound care and healing agents due to the nature of the wound healing process, which is highly complex and highly exposed to external infection. Phytochemical and pharmacological evidence has supported the ethnopharmacological use of stingless bee honey in wound care. All of these beneficial effects could enhance the stingless bee honey profile as a wound healing agent. Historically, the application of honey to the wound has been used since ancient times; therefore, it is essential to understand its pharmacological action towards the physiology of the wounded skin in order to optimize the healing rate. Stingless bee honey has a lot of similarities with other honeys in terms of its bioactive components, but the efficacy of the components has yet to be discovered. As a result, more systematic research is needed to provide comprehensive scientific evidence for its use as well as to clarify any doubt and false acclaim. The potent biological activities of stingless bee honey may create a new therapeutic choice from the current honey and represent an interesting advance in the search for promising applications in the pharmaceutical industry for the wound healing area.

\section{Acknowledgment}

This study was carried out with the support of a grant provided by the Ministry of Education, Malaysia (FRGS16-043-0542).

\section{Disclosure Statement}

There is no conflict of interest.
Abd Jalil/Kasmuri/Hadi 


\section{References}

1 Rasmussen C, Cameron SA: Global stingless bee phylogeny supports ancient divergence, vicariance, and long distance dispersal. Biol J Linn Soc 2010;99:206-232.

2 Michener CD: Pot-Honey: A Legacy of Stingless Bees. New York, Springer, 2013. DOI: 10.1007/978-1-4614-4960-7

3 Slaa EJ, Chaves L, Malagodi-Braga K, Hofstede FE: Stingless bees in applied pollination: practice and perspectives. Apidologie 2006; 37:293-315.

4 Ayala R, Gonzalez VH, Engel MS: Mexican stingless bees (Hymenoptera: Apidae): diversity, distribution, and indigenous knowledge; in Vit P, Pedro SRM, Roubik DW (eds): PotHoney. New York, Springer, 2013, pp 135152.

5 Khairunnisa S: Stingless Bee Potential. Kuala Lumpur, Utusan Malaysia, 2011. http://ww1. utusan.com.my/utusan/info.asp? $y=$ $2011 \& \mathrm{dt}=0530 \& p u b=$ utusan_malaysia\&sec $=$ Agrobiz\&pg=ag_02.htm.

6 Guerrini A, Bruni R, Maietti S, Poli F, Rossi D, Paganetto G, et al: Ecuadorian stingless bee (Meliponinae) honey: a chemical and functional profile of an ancient health product. Food Chem 2009;114:1413-1420.

7 Bankova V: Chemical diversity of propolis makes it a valuable source of new biologically active compounds. J ApiProduct ApiMed Sci 2009; $1: 23-28$

8 dos Santos CG, Megiolaro FL, Serrao JE, Blochtein B: Morphology of the head salivary and intramandibular glands of the stingless bee Plebeia emerina (Hymenoptera: Meliponini) workers associated with propolis. Ann Entomol Soc Am 2009;102:137-143.

9 Simone-Finstrom M, Spivak M: Propolis and bee health: the natural history and significance of resin use by honey bees. Apidologie 2010;41:295-311.

10 Temaru E, Shimura S, Amano K, Karasawa T: Antibacterial activity of honey from stingless honeybees (Hymenoptera; Apidae; Meliponinae). Polish J Microbiol 2007;56:281-285.

11 Massaro FC, Brooks PR, Wallace HM, Russell FD: Cerumen of Australian stingless bees (Tetragonula carbonaria): gas chromatography-mass spectrometry fingerprints and potential anti-inflammatory properties. Naturwissenschaften 2011;98:329-337.

12 Menezes C, Vollet-Neto A, Contrera FAFL, Venturieri GC, Imperatriz-Fonseca VL: The role of useful microorganisms to stingless bees and stingless beekeeping; in Pot-Honey: A Legacy of Stingless Bees. New York, Springer, 2013, pp 153-171.

13 Anderson KE, Sheehan TH, Eckholm BJ, Mott BM, DeGrandi-Hoffman G: An emerging paradigm of colony health: microbial balance of the honey bee and hive (Apis mellifera). Insectes Soc 2011;58:431-444.

14 Nogueira-Neto P: Vida e Criação de Abelhas Indígenas Sem Ferrão. São Paulo, Editora Nogueirapis, 1997.
15 Souza B, Roubik D, Barth O, Heard T, Enríquez $\mathrm{E}$, Carvalho $\mathrm{C}$, et al: Composition of stingless bee honey: setting quality standards. Interciencia 2006;31:867-875.

16 Bijlsma L, De Bruijn LLM, Martens EP, Sommeijer MJ: Water content of stingless bee honeys (Apidae, Meliponini): interspecific variation and comparison with honey of Apis mellifera. Apidologie 2006;37:480-486.

17 Costa RAC, Da Cruz-Landim C: Hydrolases in the hypopharyngeal glands of workers of Scaptotrigona postica and Apis mellifera (Hymenoptera, Apinae). Genet Mol Res 2005;4: 616-623.

18 Jackson WM, Nesti LJ, Tuan RS: Concise review: clinical translation of wound healing therapies based on mesenchymal stem cells. Stem Cells Transl Med 2012;1:44-50.

19 Guo S, DiPietro LA: Factors affecting wound healing. J Dent Res 2010;89:219-229.

20 Dobanovački D, Milovanović L, Slavković A Tatić M, Mišković SS, Škorić-Jokić S, et al: Surgery before common era (BCE). Arch Oncol 2012;20:28-35

21 Ahmed AKJ, Hoekstra MJ, Hage JJ, Karim RB: Honey-medicated dressing: transformation of an ancient remedy into modern therapy. Ann Plast Surg 2003;50:143-147; discussion 147-148.

22 Vandamme L, Heyneman A, Hoeksema H, Verbelen J, Monstrey S: Honey in modern wound care: a systematic review. Burns 2013; 39:1514-1525.

23 Bergman A, Yanai J, Weiss J, Bell D, David MP: Acceleration of wound healing by topical application of honey: an animal model. Am J Surg 1983;145:374-376.

24 Al-Waili N, Salom K, Al-Ghamdi A: Honey for wound healing, ulcers, and burns; data supporting its use in clinical practice. Sci World J 2011;11:766-787.

25 Azim MK, Perveen H, Mesaik MA, Simjee SU: Antinociceptive activity of natural honey in thermal-nociception models in mice. Phytother Res 2007;21:194-197.

26 Küpeli Akkol E, Orhan DD, Gürbüz I, Yesilada E: In vivo activity assessment of a "honeybee pollen mix" formulation. Pharm Biol 2010;48:253-259.

27 Tonks AJ, Dudley E, Porter NG, Parton J, Brazier J, Smith EL, et al: A 5.8-kDa component of manuka honey stimulates immune cells via TLR4. J Leukoc Biol 2007;82:1147-1155.

28 Kassim M, Yusoff KM, Ong G, Sekaran S, Yusof MYBM, Mansor M: Gelam honey inhibits lipopolysaccharide-induced endotoxemia in rats through the induction of heme oxygenase- 1 and the inhibition of cytokines, nitric oxide, and high-mobility group protein B1. Fitoterapia 2012;83:1054-1059.

29 Azim MK, Sajid M: Evaluation of nematocidal activity in natural honey. Pakistan J Bot 2009;41:3261-3264.
30 Sajid M, Azim MK: Characterization of the nematicidal activity of natural honey. J Agric Food Chem 2012;60:7428-7434.

31 Ahmad I, Jimenez H, Yaacob NS, Yusuf N: Tualang honey protects keratinocytes from ultraviolet radiation-induced inflammation and DNA damage. Photochem Photobiol 2012;88:1198-1204.

32 D'Errico M, Lemma T, Calcagnile A, Santis LP De, Dogliotti E: Cell type and DNA damage specific response of human skin cells to environmental agents. Mutat Res Mol Mech Mutagen 2007;614:37-47.

33 Wijesinghe WAP, Jeon YJ: Biological activities and potential cosmeceutical applications of bioactive components from brown seaweeds: a review. Phytochem Rev 2011;10: 431-443.

34 Victor VM, Rocha M, De La Fuente M: Immune cells: free radicals and antioxidants in sepsis. Int Immunopharmacol 2004;4:327-347.

35 Ju HY, Chen SC, Wu KJ, Kuo HC, Hseu YC, Ching $\mathrm{H}$, et al: Antioxidant phenolic profile from ethyl acetate fraction of Fructus Ligustri Lucidi with protection against hydrogen peroxide-induced oxidative damage in SH-SY5Y cells. Food Chem Toxicol 2012;50:492-502.

36 Closa D, Folch-Puy E: Oxygen free radicals and the systemic inflammatory response. IUBMB Life 2004;56:185-191.

37 Closa D: Free radicals and acute pancreatitis: much ado about ... something. Free Radic Res 2013;47:934-940.

38 Fang YZ, Yang S, Wu G: Free radicals, antioxidants, and nutrition. Nutrition 2002;18: 872-879.

39 Campos JF, dos Santos UP, Macorini LFB, de Melo AMMF, Balestieri JBP, Paredes-Gamero EJ, et al: Antimicrobial, antioxidant and cytotoxic activities of propolis from Melipona orbignyi (Hymenoptera, Apidae). Food Chem Toxicol 2014;65:374-380.

40 Matés JM, Pérez-Gómez C, Núñez de Castro I: Antioxidant enzymes and human diseases. Clin Biochem 1999;32:595-603.

41 Baskar AA, Al Numair KS, Gabriel Paulraj M, Alsaif MA, Muamar M Al, Ignacimuthu S: $\beta$-Sitosterol prevents lipid peroxidation and improves antioxidant status and histoarchitecture in rats with 1,2-dimethylhydrazineinduced colon cancer. J Med Food 2012;15: 335-343.

42 Ahmad P, Jaleel CA, Salem M, Nabi G, Sharma S: Roles of enzymatic and nonenzymatic antioxidants in plants during abiotic stress. Crit Rev Biotechnol 2010;30:161-175.

43 Khalil MI, Alam N, Moniruzzaman M, Sulaiman SA, Gan SH: Phenolic acid composition and antioxidant properties of Malaysian honeys. J Food Sci 2011;76:C921-C928.

44 Oddo LP, Heard TA, Rodríguez-Malaver A, Pérez RA, Fernández-Muiño M, Sancho MT, et al: Composition and antioxidant activity of Trigona carbonaria honey from Australia. J Med Food 2008;11:789-794. 
45 Isla M, Cordero A, Diaz L, Perez-Perez EM, Vit P: Cosmetic properties of honey; in Vit P, Roubik D (eds): Stingless Bees Process Honey and Pollen in Cerumen Pots. Mérida, Universidad de Los Andes, 2013, pp 1-8.

46 Mohd N, Mohd F, Sajap AS, Rosliza J, Suri R: Conservation and sustainable utilization of stingless bees for pollination services in agricultural ecosystems in Malaysia. Int Semin Enhanc Funct Biodivers Relev to Sustain Food Prod ASPAC, 2010, pp 1-11.

47 Kakkar S, Bais S: A review on protocatechuic acid and its pharmacological potential. ISRN Pharmacol 2014;2014:952943.

48 Takahama U, Hirota S, Nishioka T, Oniki T: Human salivary peroxidase-catalyzed oxidation of nitrite and nitration of salivary components 4-hydroxyphenylacetic acid and proteins. Arch Oral Biol 2003;48:679-690.

49 Biskup I, Golonka I, Gamian A, Sroka Z: Antioxidant activity of selected phenols estimated by ABTS and FRAP methods. Postepy Hig Med Dosw (Online) 2013;67:958-963.

50 Dutra RP, Nogueira AMC, Marques RRDO, Costa MCP, Ribeiro MNS: Pharmacognostic evaluation of geopropolis of Melipona fasciculata Smith from Baixada Maranhense, Brazil. Braz J Pharmacogn 2008; 18:557-562.

51 Sawaya A, Barbosa da Silva Cunha I, Marcucci M: Analytical methods applied to diverse types of Brazilian propolis. Chem Cent J 2011; 5:27.

52 Alvarez-Suarez JM, Giampieri F, GonzálezParamás AM, Damiani E, Astolfi P, MartinezSanchez G, et al: Phenolics from monofloral honeys protect human erythrocyte membranes against oxidative damage. Food Chem Toxicol 2012;50:1508-1516.

53 Vowden K, Vowden P, Carville K: Antimicrobial dressings made easy. Wounds Int 2011;2: $1-6$.

54 Li J, Chen J, Kirsner R: Pathophysiology of acute wound healing. Clin Dermatol 2007;25: 9-18.

55 Korting H, Schöllmann C, White R: Management of minor acute cutaneous wounds: importance of wound healing in a moist environment. J Eur Acad Dermatol Venereol 2011;25:130-137.

56 Martin P: Wound healing - aiming for perfect skin regeneration. Science 1997;276:75-81.

57 Heng MCY: Wound healing in adult skin: aiming for perfect regeneration. Int J Dermatol 2011;50:1058-1066.

58 Cano RJ, Borucki MK, Higby-Schweitzer M, Poinar HN, Poinar Jnr GO, Pollard KJ: Bacillus DNA in fossil bees: an ancient symbiosis? Appl Environ Microbiol 1994;60:2164-2167.

59 Yoshiyama M, Kimura K: Characterization of antimicrobial peptide genes from Japanese honeybee Apis cerana japonica (Hymenoptera: Apidae). Appl Entomol Zool 2010;45: 609-614.

60 Promnuan Y, Kudo T, Chantawannakul P: Actinomycetes isolated from beehives in Thailand. World J Microbiol Biotechnol 2009;25:1685-1689.
61 Siddiqui AR, Bernstein JM: Chronic wound infection: facts and controversies. Clin Dermatol 2010;28:519-526.

62 Gerding DN: Foot infections in diabetic patients: the role of anaerobes. Clin Infect Dis 1995;20(suppl 2):S283-S288.

63 Krasner D: Minimizing factors that impair wound healing: a nursing approach. Ostomy Wound Manage 1995;41:22-26, 28, 30-32.

64 Irish J, Carter DA, Blair SE, Heard TA: Antibacterial activity of honey from the Australian stingless bee Trigona carbonaria. Int J Antimicrob Agents 2008;32:89-90.

65 Boorn KL, Khor YY, Sweetman E, Tan F, Heard TA, Hammer KA: Antimicrobial activity of honey from the stingless bee Trigona carbonaria determined by agar diffusion, agar dilution, broth microdilution and time-kill methodology. J Appl Microbiol 2010;108: 1534-1543.

66 Pimentel RB de Q, da Costa CA, Albuquerque PM, Junior SD: Antimicrobial activity and rutin identification of honey produced by the stingless bee Melipona compressipes manaosensis and commercial honey. BMC Complement Altern Med 2013;13:151.

67 Choudhari MK, Punekar SA, Ranade RV, Paknikar KM: Antimicrobial activity of stingless bee (Trigona sp.) propolis used in the folk medicine of Western Maharashtra, India. J Ethnopharmacol 2012;141:363-367.

68 Molan PC: Honey: Antimicrobial actions and role in disease management; in Ahmad I, Aqil F (eds): New Strategies Combating Bacterial Infection. Hoboken, Wiley-Blackwell, 2009, pp 229-253.

69 White JW, Subers MH, Schepartz AI: The identification of inhibine, the antibacterial factor in honey, as hydrogen peroxide and its origin in a honey glucose-oxidase system. Biochim Biophys Acta 1963;73:57-70.

70 Zainol M, Mohd Yusoff K, Mohd Yusof M: Antibacterial activity of selected Malaysian honey. BMC Complement Altern Med 2013; 13:129.

71 Tan H, Rahman R, Gan S, Halim A, Hassan S, Sulaiman S, et al: The antibacterial properties of Malaysian tualang honey against wound and enteric microorganisms in comparison to manuka honey. BMC Complement Altern Med 2009;9:34.

72 Mandal MD, Mandal S: Honey: its medicinal property and antibacterial activity. Asian Pac J Trop Biomed 2011;1:154-160.

73 Koochak H, Seyyednejad SM, Motamedi H: Preliminary study on the antibacterial activity of some medicinal plants of Khuzestan (Iran). Asian Pac J Trop Med 2010;3:180-184.

74 Stow A, Briscoe D, Gillings M, Holley M, Smith S, Leys R, et al: Antimicrobial defences increase with sociality in bees. Biol Lett 2007; 3:422-424
75 Ewnetu Y, Lemma W, Birhane N: Antibacterial effects of Apis mellifera and stingless bee honeys on susceptible and resistant strains of Escherichia coli, Staphylococcus aureus and Klebsiella pneumoniae in Gondar, Northwest Ethiopia. BMC Complement Altern Med 2013;13:269.

76 Boscá L, Zeini M, Través PG, Hortelano S: Nitric oxide and cell viability in inflammatory cells: a role for $\mathrm{NO}$ in macrophage function and fate. Toxicology 2005;208:249-258.

77 Kim KN, Ko YJ, Yang HM, Ham YM, Roh SW, Jeon YJ, et al: Anti-inflammatory effect of essential oil and its constituents from fingered citron (Citrus medica L. var. sarcodactylis) through blocking JNK, ERK and NF- $\mathrm{KB}$ signaling pathways in LPS-activated RAW 264.7 cells. Food Chem Toxicol 2013;57:126131.

78 Kazłowska K, Hsu T, Hou CC, Yang WC, Tsai GJ: Anti-inflammatory properties of phenolic compounds and crude extract from Porphyra dentata. J Ethnopharmacol 2010;128:123130.

79 Jones MK, Wang H, Peskar BM, Levin E, Itani RM, Sarfeh IJ, et al: Inhibition of angiogenesis by nonsteroidal anti-inflammatory drugs: insight into mechanisms and implications for cancer growth and ulcer healing. Nat Med 1999;5:1418-1423.

80 Krischak GD, Augat P, Claes L, Kinzl L, Beck $A$ : The effects of non-steroidal anti-inflammatory drug application on incisional wound healing in rats. J Wound Care 2007;16:76-78.

81 Mulder GD, Vande Berg JS: Cellular senescence and matrix metalloproteinase activity in chronic wounds. Relevance to debridement and new technologies. J Am Podiatr Med Assoc 2002;92:34-37.

82 Schreml S, Szeimies R-M, Prantl L, Landthaler M, Babilas P: Wound healing in the 21st century. J Am Acad Dermatol 2010;63:866881.

83 Shamaki BU, Yusuf A, Balla HJ, Halima IG, Sherifat OB, Abdulrahman FI, et al: Evaluation of chemical composition and the comparative wound healing effect of natural honey and olive oil in rabbits. Infin Commun Appl Sci 2014;2:149-169.

84 Franchin M, Da Cunha MG, Denny C, Napimoga MH, Cunha TM, Koo H, et al: Geopropolis from Melipona scutellaris decreases the mechanical inflammatory hypernociception by inhibiting the production of IL- $1 \mathrm{~b}$ and TNF- $\alpha$ J Ethnopharmacol 2012;143:709-715.

85 Kassim M, Achoui M, Mustafa MR, Mohd MA, Yusoff KM: Ellagic acid, phenolic acids, and flavonoids in Malaysian honey extracts demonstrate in vitro anti-inflammatory activity. Nutr Res 2010;30:650-659.

86 Hussein SZ, Mohd Yusoff K, Makpol S, Mohd Yusof YA: Gelam honey inhibits the production of proinflammatory, mediators NO, PGE 2 , TNF- $\alpha$, and IL- 6 in carrageenan-induced acute paw edema in rats. Evid Based Complement Alternat Med 2012;2012:109636. 
87 Aljadi AM, Kamaruddin MY: Evaluation of the phenolic contents and antioxidant capacities of two Malaysian floral honeys. Food Chem 2004;85:513-518.

88 Alvarez-Suarez JM, Tulipani S, Romandini S, Bertoli E, Battino M: Contribution of honey in nutrition and human health: a review. Med J Nutrition Metab 2010;3:15-23.

89 Molan PC: The evidence and the rationale for the use of honey as a wound dressing. Wound Pract Res 2011;19:204-220.

90 Boateng JS, Matthews KH, Stevens HNE, Eccleston GM: Wound healing dressings and drug delivery systems: a review. J Pharm Sci 2008;97:2892-2923.

91 Schultz GS, Sibbald RG, Falanga V, Ayello EA, Dowsett C, Harding K, et al: Wound bed preparation: a systematic approach to wound management. Wound Repair Regen 2003;11: $2-21$.

92 Davis SC, Perez R: Cosmeceuticals and natural products: wound healing. Clin Dermatol 2009;27:502-506
93 Kurhade S, Momin M, Khanekar P, Mhatre S: Novel biocompatible honey hydrogel wound healing sponge for chronic ulcers. Int J Drug Deliv 2013;5:353-361.

94 Atiyeh BS, Amm CA, El Musa KA: Improved scar quality following primary and secondary healing of cutaneous wounds. Aesthetic Plast Surg 2003;27:411-417.

95 Atiyeh BS, Hayek SN: Moisture and wound healing. J Plaies Cicatrisation 2005;9:7-11.

96 Ediriweera ERHSS, Premarathna NYS: Medicinal and cosmetic uses of bee's honey - a review. Ayu 2012;33:178-182.

97 Bikowski J: The use of therapeutic moisturizers in various dermatologic disorders. Cutis Cutan Med Pract 2001;68:3-11.

98 Draelos ZD: Active agents in common skin care products. Plast Reconstr Surg 2010;125: 719-724.

99 Ciulu M, Solinas S, Floris I, Panzanelli A, Pilo MI, Piu PC, et al: RP-HPLC determination of water-soluble vitamins in honey. Talanta 2011;83:924-929.
100 Tuberoso CIG, Jerković I, Bifulco E, Marijanovic Z, Congiu F, Bubalo D: Riboflavin and lumichrome in Dalmatian sage honey and other unifloral honeys determined by LC-DAD technique. Food Chem 2012;135: 1985-1990.

101 Vanhanen LP, Emmertz A, Savage GP: Mineral analysis of mono-floral New Zealand honey. Food Chem 2011;128:236-240.

102 Molan PC: Potential of honey in the treatment of wounds and burns. Am J Clin Dermatol 2001;2:13-19.

103 Ovington LG: Advances in wound dressings. Clin Dermatol 2007;25:33-38.

104 Truchado P, Vit P, Ferreres F, Tomas-Barberan F: Liquid chromatography-tandem mass spectrometry analysis allows the simultaneous characterization of $C$-glycosyl and $O$-glycosyl flavonoids in stingless bee honeys. J Chromatogr A 2011;1218:7601-7607.

105 Suntiparapop K, Prapaipong P, Chantawannakul P: Chemical and biological properties of honey from Thai stingless bee (Tetragonula leaviceps). J Apic Res 2012;51:45-52. 